\title{
セダム属数種の塩ストレスについて
}

\section{On the Responses of Sedums to Salt Stress}

\author{
飯島健太郎* ${ }^{*}$ 近藤三雄 ${ }^{*}$ \\ Kentaro IIJIMA Mitsuo KONDO
}

\begin{abstract}
摘要：臨海地の緑化材料としての可能性を明らかにするためにセダム属数種の耐塩性について検討し た。海水処理による生存日数からタイトゴメが最も耐塩性に富み、マルバマンネングサ, メキシコマ ンネングサ, ッルマンネングサは早期に枯死した。健全に生育している時よりも水ストレス時の方が 耐塩性が増加した。次に塩分濃度とその施用方法の異なる条件下での反応では, 食塩水が土壇に灌注 されることによる影響が大きく，2.5 3.0\%浱度ではメキシコマンネングサは枯死，タイトゴメは顕 著に生育が抑制され，根からの塩分の吸収による被害が大きかった。しかし茎葉に散布される場合に は影譬は少なく，地上部への塩分に対する抵抗性に富んでいた。
\end{abstract}

\section{1. 研究目的}

臨海副都心のような都市空間の臨海地への拡大, アクアライン のような道路が海上を横断するケースなどが増加し，それに伴う 緑化や一方では降雪地の凍結防止剂の多用等によって, 塩分が植 栽に与える影響が懸念されている。またその影響は, 塩分の濃度 あるいは土壌中に浸透したり潮風として茎葉に付着するケースな ぞ，さまざまな状況が想定される。この分野ではすでに海浜植物 の生理的特性として土壤中の塩分あるいは潮風等の地上部への塩 分に対する抵抗性についての知見がある。また耐塩性については, (1)植物の形態変化による耐性獲得, (2)細胞内の浸透圧調節機構, (3)選択的 $\mathrm{K}$ 吸収能に関連した $\mathrm{Na}$ の排除能, (4)Salt gland の形 成による塩の排出, (5)体内の高濃度耐性などのメカニズムが説明 されている ${ }^{9)}$ 。

緑化用地被材料としてのセダム類の中には海岸を自生地とする 種類もあり，耐塩性に富むことが予想されるが，その点について の知見は少ない。多肉植物の塩反応については, Mesembryanthemum crystallinum ${ }^{11.121 .134)}$, Aster tripolium ${ }^{2)}$, Portulacaria afra ${ }^{10)}$, Peperomia obtusifolia ${ }^{3)}$ な゙の種類で, 塩処 理によって夜間の $\mathrm{CO}_{2}$ 吸収や有機酸の蓄積などの現象から, CAM 型光合成が誘導される反応が報告されている。但しその反 応は, 塩処理に伴って起きる水ストレスに対する適応反応である と考えられている。その点ではセダムについてあ水ストレスによっ て CAM 型光合成が誘導される現象が確認されており ${ }^{5.6 .7)}$, 塩処 理によっても同様の現象が誘導されることが予想される。しかし， 海水に近いような高濃度塩分による影響や地下部・地上部に受け る場合の反応については明らかではない。

そこで本研究では, 数種のセダム類を用いて, その生育状態, 塩分の濃度やその受け方の違い等による反応について把握するこ とを目的に一連の実験を行った。

\section{2. 実験内容と方法}

まず(1)数種セダムの耐塩性の差異，(2)セダムの生育状態による 耐塩性の差異について検討した。次に, より詳細に(3)塩分濃度, (4)塩分の施用方法の差異による被害状態や生育抑制の度合を比較 検討した。

（1）数種セダムの耐塩性の比較と生育状態による耐塩性の差異 供試植物はマルバマンネングサ（Sedum makinoi：横浜市内
採取), メキシコマンネングサ (S. mexicanum: 横浜市内採取), タイトゴメ（S. oryzifolium: 横須賀市内採取), ツルマンネン グサ（S. sarmentosum：横浜市内採取）とした。

各地で, いずれも 1999 年6月 7 日に採取したセダム各種のシュー 卜を海水に漬け, その後の生存状況について調查した。実験に先 立ち海水を横須賀市で採取し，明期 $(12 \mathrm{H}) /$ 暗期 $(12 \mathrm{H}): 20 / 15^{\circ} \mathrm{C}$ の人工環境室内に設置した $30 \mathrm{~cm}$ 水槽内に注ぎ，含有有機物類の 腐敗を防ぐためにポンプで盾環した。使用した海水は，水素イオ ン濃度 8.2 , 塩素イオン $17466 \mathrm{mg} / \mathrm{l}$ ，ナトリウム $9803 \mathrm{mg} / \ell$ どあっ た。なお海水は約 $465 \mathrm{mM}$ の $\mathrm{NaCl}$ を含むと言われている ${ }^{8)}$ 。

採取直後の各種のセダムのシュートを海水に漬け，1，2，3， 4,5 日後に, シュートを 5 個体ずつ海水から取り出し, 生存確 認を行った（以後この処理を海水処理という）。確認の方法は, 同人工環境室内に設置した培土（湿潤状態の黒ぼく土の下層土） 上にシュートをのせ, 発根や新葉の展開が認められれば生存して いたとし, 認められなかった場合には枯死とした。海水からの取 り出しに際し, 海水の水によるシュートの洗浄効果について検討 するために，水道水を入れたビーカー内にシュートを沈めて 5 分 間擋拌し，回復確認を行う区を設けた（以後これを洗浄区之よぶ）。

さらに耐塩性は生育状態によっても違いがあると考えられるの で健全生育している苗と水ストレス苗との比較を行うために, 採 取直後の健全生育している苗とは別に採取後人工環境調節室（設 定気温 $20 / 15^{\circ} \mathrm{C}$, 設定湿度 30 40\%）に8 週間置き，水ストレ ス状態にした苗についても同様に処理した。水ストレスの度合は, 4 種共に採取時に対して $50 \%$ 前後の生体重量となっており（図一 1 ), この段階の葉の水ポテンシャルは既往研究から ${ }^{4)}$ 約 $-1.0 \mathrm{M}$ $\mathrm{Pa}$ であることが予想された。

なお，タイトゴメのみ海水処理後のシュート内のナトリウム濃 度の計測を行った。

\section{（２）塩分漶度と施用方法の差異によるセダムの反応}

供試植物には，メキシコマンネングサ，タイトゴメを用いた。 実験区は, 食塩水の濃度と水ポテンシャルの関係（図一2）を 基に, 食塩濃度で $3.0 \%, 2.5 \%, 1.5 \% ， 1.0 \%$ 区の 4 水準とし, 施用方法は (a)土壌灌注区（以下，灌注区)，（b)植物体散布区 (以下, 散布区), (c) 土壤灌注・植物体散布併用区（以下，併用 区）の 3 施用区とした。また水ストレスのみの条件と比較するた

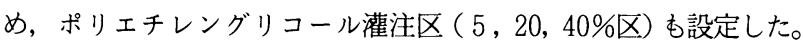


実験に先立ち，1998 年 6 月 20 日に黒土を充填した NEUBAUER'S POT に供試植物 2 種を植付け養生した。実験 は同年 10 月 10 日に開始し，降雨による影響を避けるために東京 都世田谷区大学構内のガラス室内で翌年 1 月 10 日まで行った。 実験期間中のガラス室内の気温条件は図 -3 に示した。実験期間 中の土䁃状態を明らかにするため，10月下旬，11月中旬，12 月 上旬の 3 回土壤中の水ポテンシャル（図一 - 4) ならびに塩分濃度 (図一 5 ) の計測を行った。その結果, 実験期間中に若干濃度の 変動が見られたが概ね各段階の濃度に維持できた。

生育や被害の状態は実験終了時の生体重量, シュート数, 葉内 水ポテンシャルによって評価した。土壌ならびに葉の水ポテンシャ ルは, Dew Point Microvoltmeter-HR33T, C-52 Sample Chamber（米国 WESCOR 社製）を使用した。

\section{3. 実験結果と考察}

（1）数種セダムの耐塩性の比較と生育状態による耐塩性の差異

(i ) 生存日数からみた各種の耐塩性（表一1）

自生地から採取直後のマルバマンネングサ, メキシコマンネン グサ, ツルマンネングサのシュートでは, 既に 1 日間の海水処理 でも回復は認められず枯死していたが，タイトゴメは 3 日間の海 水処理でも回復した。水ストレス状態になるとマルバマンネング サ,メキシコマンネングサ, タイトゴメでは回復可能な海水処理 日数が若干延長された。

さらに採取直後, あるいは水ストレスの苗共にいずれの種類も 海水処理後, 洗浄処理を加えると若干回復可能な日数が延長され た。

なお, ッルマンネングサについては, 水ストレスの苗のみ, 海 水処理後, 洗浄処理することによって数日間は回復したが, 葉部 は欠落し茎部のみが生存し, 後に葉が発生する現象か認められた。

(ii）タイトゴメの植物体内ナトリウム濃度について（図一-6）

自生地より採取後のタイトゴメは, $1.5 \mathrm{mg} / \mathrm{g}$ (生体重量) のナ トリウムを含有していた。海水処理後, 日数経過に伴って含有率 は上昇し， 2 日後には $5 \mathrm{mg} / \mathrm{g}, 3 \sim 4$ 日後には $8 \mathrm{mg} / \mathrm{g}$ 前後まで 上昇した。この $3 \sim 4$ 日間に回復不可能な苗が発生していた。水 ストレス苗では, 海水処理 1〜3日で $9 \mathrm{mg} / \mathrm{g}$ 前後を示し, $4 \sim$ 5 日後に $11 \mathrm{mg} / \mathrm{g}$ となり,この $4 \sim 5$ 日間に回復不可能な苗が発 生していた。

\section{(iii) 考察}

いずれの種類も採取直後の苗よりも水ストレス状態であると海 水処理後の回復可能性が増大した。水ストレス状態となったセダ ム類は, 葉中の水ポテンシャルの低下が起こり, これが海水の葉 中への浸入を軽減した可能性がある。

一方, 採取直後の苗あるいは水ストレス状態の苗共に, 洗浄処理

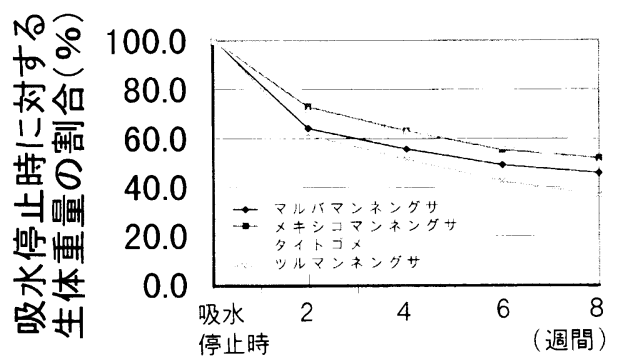

吸水停止後の経過日数

図-1 吸水停止後のセダムの生体重量の変化
区では, 海水処理後の回復可能性を増大した。これはナトリウム の浸入した葉中と水道水との間に大きく水ポテンシャルの勾配が 生じ, 葉中のナトリウムを希釈して被害を軽減した可能性むある。

実験で用いた 4 種類のセダム類では, タイトゴメが最も耐潮性 に富み, ッルマネングサが最も劣った。この違いは葉の形状にも 起因すると考えられる。すなわち, タイトゴメは葉厚が厚く多汁 度が高いのに対し, ツルマンネングサは葉が薄く塩分の影響を受 けやすいことが考えられる。

なお本実験で供試した三浦半島産の夕イトゴメは三倍体で不稔 性である。自生地の海岸においては, 風雨や高波によってちぎれ たシュートが水ストレス状態となって軽量化となり，これがさら に風雨や波によって移動し, 新しい土地で活着することは, 本種 の分布拡大のメカニズムとして有意義であると思われる。さらに 新しい土地に流れ着き, 降雨によって塩ストレスが緩和されるな らば, 若干の生存の可能性を広げる要因にもなると考えられる。

（2）塩分漕度と施用方法の差異によるセダムの反応

(i) 生体重量とシュート数 (表一2)

メキシコマンネングサでは, 併用区の 2.5 3.0\%区では実験開 始後直ちに被害が現れ枯死した。対照区における生体重量の増加 比は 55.0 に対して, いずれの施用方法においても濃度が濃くな るほど生育が抑制され，濃度 $3 \%$ 区では灌注区之散布区では増加 比 3.0 前後であった。しかし濃度 $1 \%$ 区では施用方法による差が 顕著であり, 散布区の生体重量の増加比は 27.0 であるのに対し, 灌注区と併用区では 6.0 となり，ポリエチレングリコール灌注区 についても 40〜20\%区で増加比 7前後になっていた。同様にシュー
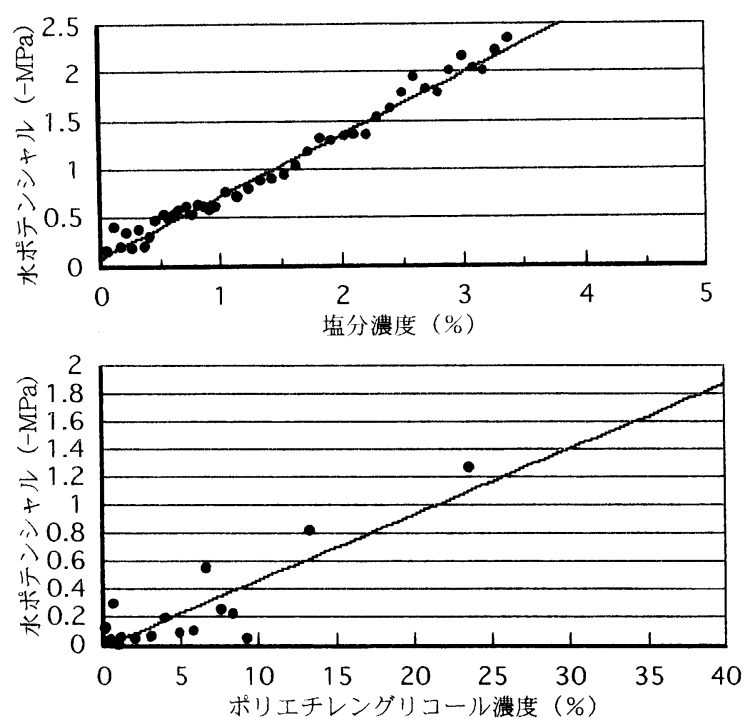

図－２塩分濃度・ポリエチレングリコール浱度と 水ポテンシャルの関係

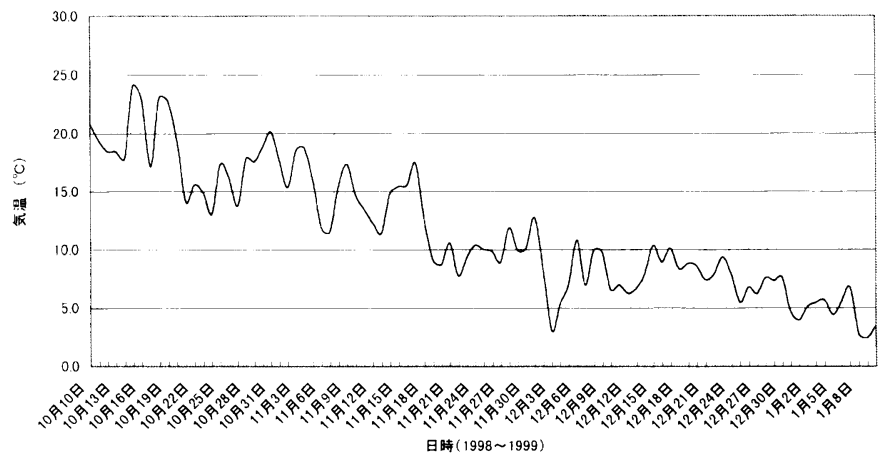

図ー3 実験期間中のガラス室内日平均気温の変化 


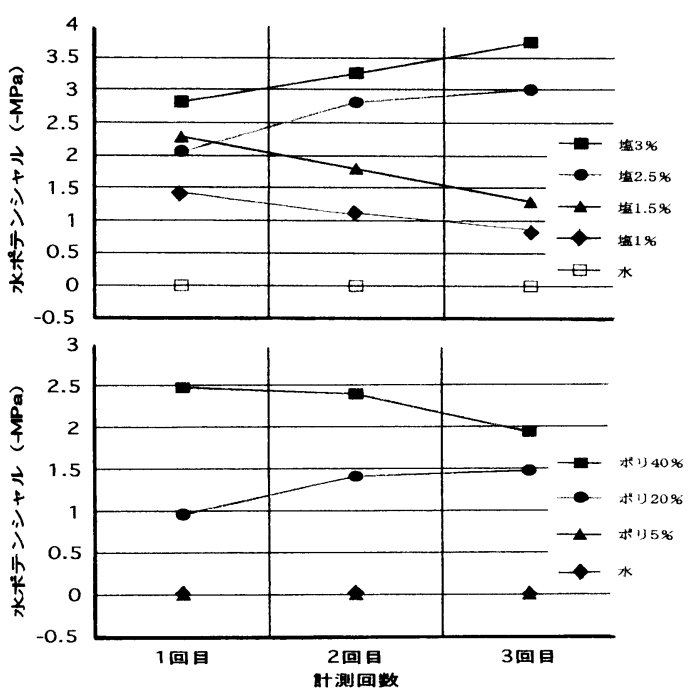

図－4＼cjkstart食塩水潅注区，ポリエチレングリコール水溶液 潅注区の実験期間中の土袞水分ポテンシャル

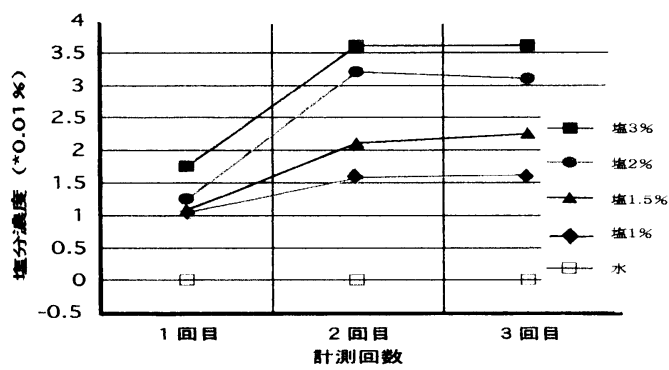

図一 5 食塩水潅注区の実験期間中の土壤中塩分濃度

卜数についても対照区の増加比約 2.0 に対して，ポリエチレング リコール灌注区において 40 20\%で増加比 2.0 前後，散布区の $2.5 \%, 1.5 \%, 1.0 \%$ 区で増加比 1.0 1.6，それ以外は全ての施 用区で減少傾向にあり，生育の抑制が顕著であった。

タイトゴメでは生育状態に差が認められるあのの，すべての施 用区に打いて生体重量とシュート数の増加が認められた。しかし 施用方法による生育の抑制度合の差が顕著であり，対照区の生体 重量の増加比が 27.0 であるのに対して, 灌注区と併用区の 2.5 $3.0 \%$ 区では増加比 5.0 前後, $1.5 \sim 1.0 \%$ 区では 10.0 前後となっ ていた。散布区では，対照区を上回る生育状態を示し，1.0\%， 1.5\%，2.5\%区の生体重量の増加比 30.0 前後， $3.0 \%$ 区では 50.0 となっていた。それに比較してポリエチレングリコール 20\%灌 注区では増加比は $9 ， 40 \%$ 灌注区では増加比は約 3 と生育が抑制 された。シュート数についても同様の傾向が認められ, 散布区で は対照区よりも増加比が高かった。

（ii）葉内の水ポテンシャル（表一 3 ）

対照区の葉の水ポテンシャルは両種ともにー $0.4 \mathrm{MPa}$ 前後となっ たが，施用区ではいずれも低下し，特に灌注区では－1.0MPa 前 後に達していた。ポリエチレングリコール灌注区では, 濃度によ る段階的な葉の水ポテンシャルの低下が認められたが, 同水ポテ ンシャルに相当する食塩水灌注区に比較すると葉の水ポテンシャ ルの低下は少なかった。

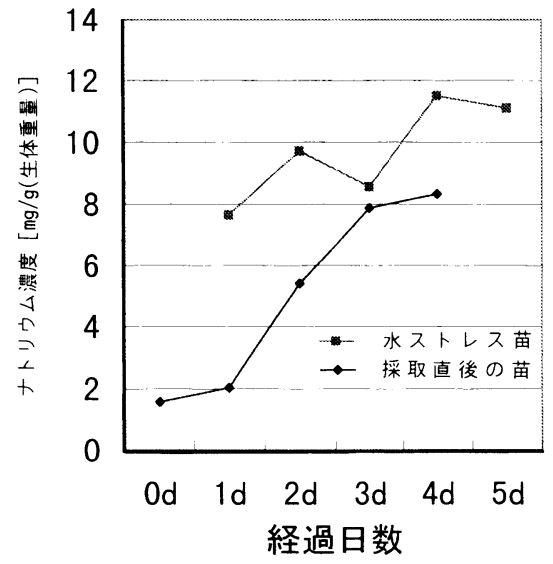

図ー6 採取直後と水ストレス状態のタイトゴメを用いた海水処 理後の日数経過に伴う体内ナトリウム濃度

表一 1 海水処理日数の違いによるセダムの生存数

\begin{tabular}{|c|c|c|c|c|c|c|c|c|c|c|c|c|}
\hline \multirow{2}{*}{ 草種 } & \multirow{2}{*}{\multicolumn{2}{|c|}{ 忛理区分 }} & \multicolumn{10}{|c|}{ 経過日数 } \\
\hline & & & $12 \mathrm{~h}$ & $1 \mathrm{~d}$ & $2 d$ & $3 \mathrm{~d}$ & $4 \mathrm{~d}$ & $5 d$ & $6 \mathrm{~d}$ & $7 \mathrm{~d}$ & $8 \mathrm{~d}$ & $9 \mathrm{~d}$ \\
\hline & & $s$ & - & 0 & 0 & 0 & 0 & - & - & - & - & - \\
\hline ママルル" & 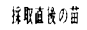 & sk & - & 4 & 0 & 0 & 0 & - & - & - & - & - \\
\hline \multirow{4}{*}{$\begin{array}{l}\text { フンンソグサ } \\
\text { S. makinoi }\end{array}$} & & w & - & 5 & 5 & 5 & 5 & 5 & 5 & - & - & - \\
\hline & & $s$ & 5 & 3 & 3 & 2 & 2 & 0 & 0 & 0 & 0 & 0 \\
\hline & 我不卜次苗 & $S W$ & 4 & 5 & 5 & 5 & 2 & 2 & 2 & 0 & 0 & 0 \\
\hline & & W & 5 & 5 & 5 & 5 & - & 5 & - & 5 & - & 5 \\
\hline \multirow{6}{*}{$\begin{array}{l}\text { イキシ } \\
\text { マンネダナ } \\
\text { S. mexicanum }\end{array}$} & & $S$ & - & 0 & 0 & 0 & 0 & - & - & - & - & - \\
\hline & 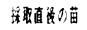 & SW & - & 3 & 0 & 0 & 0 & - & -- & -. & - & - \\
\hline & & H & - & 5 & 5 & 5 & 5 & 5 & 5 & - & - & - \\
\hline & & $s$ & 3 & 3 & 0 & 0 & 0 & - & - & - & - & - \\
\hline & 米外に又苗 & SW & 5 & 5 & 3 & 3 & 1 & 0 & 0 & 0 & - & - \\
\hline & & W & 5 & 5 & 5 & 5 & & 5 & & 5 & - & 5 \\
\hline \multirow{7}{*}{$\begin{array}{l}\text { タイトゴ } \\
\text { S. oryzifolium }\end{array}$} & & $s$ & - & 5 & 5 & 4 & 0 & 0 & 0 & 0 & - & - \\
\hline & 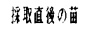 & SW & - & 5 & 5 & 5 & 3 & 0 & 0 & 0 & - & - \\
\hline & & $W$ & - & 5 & 5 & 5 & 5 & 5 & 5 & 5 & - & - \\
\hline & & s & 5 & 5 & 5 & 4 & 3 & 2 & 0 & 0 & 0 & 0 \\
\hline & 叔外々苗 & SW & 5 & 5 & 5 & 5 & 3 & 3 & 1 & 1 & 0 & 0 \\
\hline & & $W$ & 5 & 5 & 5 & 5 & - & 5 & - & 5 & - & 5 \\
\hline & & $\mathrm{S}$ & - & 0 & 0 & 0 & 0 & 0 & 0 & - & - & - \\
\hline ッル & 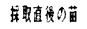 & SW & - & 0 & 0 & 0 & 0 & 0 & 0 & - & - & - \\
\hline \multirow[t]{2}{*}{ マンネングサ } & & W & - & 5 & 5 & 5 & 5 & 5 & 5 & - & - & - \\
\hline & & S & 0 & 0 & 0 & 0 & - & - & - & -- & - & - \\
\hline \multirow[t]{2}{*}{ S. samentosum } & 为不卜々苗 & SW & $5 *$ & $5 *$ & 4* & $2 *$ & 0 & 0 & 0 & - & - & - \\
\hline & & $w$ & 5 & 5 & 5 & $5 *$ & - & $5 *$ & - & $5 *$ & - & $5 *$ \\
\hline
\end{tabular}

表一２食塩水の濃度, 施用方法の異なる条件下で生育した 2 種のセダムの生体重量とシュート数

\begin{tabular}{|c|c|c|c|c|c|c|}
\hline 草種 & 実䣐 区 & 泳度 & 生体 & 量 & シュー & 卜数 \\
\hline & 刘照区 & - & 44.582 & $(55.45)$ & 73.3( & $2.02)$ \\
\hline & 土境潅注 & $3.0 \%$ & 2.081 & $(2.66)$ & 7.31 & $0.26)$ \\
\hline & & $2.5 \%$ & 3.118 & ( 2.89$)$ & $12.3 i$ & $0.30)$ \\
\hline & & $1.5 \%$ & 3.464 & $(6.02)$ & 16.3( & $0.55)$ \\
\hline & & $1.0 \%$ & 6.596 & $(6.73)$ & 34.61 & $0.86)$ \\
\hline メキシコマンネダー & 植物 体 & $3.0 \%$ & 2.944 & $(3.81)$ & 8.31 & $0.43)$ \\
\hline Sedum & 散布区 & $2.5 \%$ & 7.099 & $(12.16)$ & 22.61 & $1.01)$ \\
\hline \multirow[t]{14}{*}{ mexicanum } & & $1.5 \%$ & 13.765 & (14.98) & 41.3( & 1.41) \\
\hline & & $1.0 \%$ & 23.470 & $(27.55)$ & 59.01 & 1.61) \\
\hline & 土壤潅注 & $3.0 \%$ & 0 & $\left(\begin{array}{ll}0 & \end{array}\right)$ & 0 & $0 \quad$ \\
\hline & 植物体散布 & $2.5 \%$ & & $\left(\begin{array}{ll}0 & 1\end{array}\right)$ & 0 & $0 \quad)$ \\
\hline & 併用区 & $1.5 \%$ & 1.630 & $(1.85)$ & 6.01 & $0.32)$ \\
\hline & & $1.0 \%$ & 3.339 & $(6.19)$ & 6.31 & $0.21)$ \\
\hline & 杖りエチレン。 & $40 \%$ & 8.379 & $(6.83)$ & 74.01 & $1.70)$ \\
\hline & 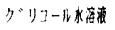 & $20 \%$ & 7.962 & ( 8.33$)$ & $75.6 i$ & 2.32) \\
\hline & 潅注 & $5 \%$ & 22.623 & $(44.98)$ & 64.61 & $2.23)$ \\
\hline & 対照区 & - & 11.795 & $(27.75)$ & 53.6 & $2.43)$ \\
\hline & 土壌潅注 & $3.0 \%$ & 2.491 & $(5.67)$ & 23.5 & 1.81) \\
\hline & & $2.5 \%$ & 2.359 & $(5.02)$ & 17.6 & 1.32) \\
\hline & & $1.5 \%$ & 3.802 & $(10.99)$ & 30.0( & 1.92) \\
\hline & & $1.0 \%$ & 6.815 & $(16.74)$ & 59.6( & 1.81) \\
\hline 夕イト & 㥀物体 & $3.0 \%$ & 16.064 & $(53.73)$ & 59.01 & $2.77)$ \\
\hline Sedurn & 散 布区 & $2.5 \%$ & 13.758 & $(28.43)$ & $60.6 i$ & $2.37)$ \\
\hline \multirow[t]{9}{*}{ orizifolium } & & $1.5 \%$ & 18.895 & $(31.28)$ & 77.61 & $3.23)$ \\
\hline & & $1.0 \%$ & 16.602 & $(28.43)$ & 70.61 & $3.07)$ \\
\hline & 土㙥浩注. & $3.0 \%$ & 1.665 & $(3.60)$ & 23.0 & 1.17) \\
\hline & 植物体散布 & $2.5 \%$ & 2.426 & $(6.68)$ & 22.3 & 1.17) \\
\hline & 併用区 & $1.5 \%$ & 3.393 & $(7.87)$ & 29.0( & 1.75) \\
\hline & & $1.0 \%$ & 5.084 & $(13.21)$ & 41.31 & 2.70) \\
\hline & ポリエチレン・ & $40 \%$ & 1.265 & $(2.83)$ & 22.61 & $1.70)$ \\
\hline & 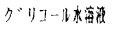 & $20 \%$ & 3.139 & $(9.40)$ & 36.31 & $1.70)$ \\
\hline & 潅注 & $5 \%$ & 7.217 & $(19.61)$ & 51.6 & 2.42) \\
\hline
\end{tabular}

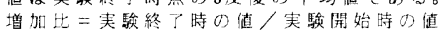


表一３＼cjkstart各処理区で生育したセダムの葉の水 ポテンシャル (MPa)

\begin{tabular}{|c|c|c|c|}
\hline 処理 区 & 濃 度 & メキシコマンネングサ & タイトゴメ \\
\hline 対照区 & - & $-0.42 \mathrm{de}$ & -0.36 ef \\
\hline \multirow[t]{4}{*}{ 土壤潅注 } & $3.0 \%$ & - & $-0.98 \mathrm{ab}$ \\
\hline & $2.5 \%$ & - & $-1.03 a$ \\
\hline & $1.5 \%$ & $-0.99 \quad a$ & $-0.83 a b c$ \\
\hline & $1.0 \%$ & $-0.89 \mathrm{ab}$ & -1.08 a \\
\hline \multirow[t]{4}{*}{ 散布区 } & $3.0 \%$ & $-0.87 a b c$ & $-0.55 \mathrm{cde}$ \\
\hline & $2.5 \%$ & $-0.90 \mathrm{ab}$ & $-0.74 \mathrm{bcd}$ \\
\hline & $1.5 \%$ & $-0.74 \mathrm{bc}$ & $-0.60 \mathrm{cde}$ \\
\hline & $1.0 \%$ & $-0.64 \mathrm{~cd}$ & $-0.47 \mathrm{def}$ \\
\hline ポリエチレン & $40 \%$ & $-0.91 \mathrm{ab}$ & $-0.67 \mathrm{~cd}$ \\
\hline \multirow[t]{2}{*}{ 潅 注 } & $20 \%$ & $-0.68 \mathrm{bc}$ & $-0.57 \mathrm{cde}$ \\
\hline & $05 \%$ & $-0.29 \mathrm{e}$ & $-0.22 \mathrm{f}$ \\
\hline
\end{tabular}

(iii) 考察

食塩水が土壌に灌注されることによる被害が著しく, 海水濃度 に近い $2.5 \sim 3.0 \%$ 濃度では，メキシコマンネングサの場合は枯死， タイトゴメの場合は生育が著しく抑制された。葉の水ポテンシャ ルについても，食塩水の施用区，特に灌注区で低下していた。ポ リエチレングリコール 40 20\%水溶液の灌注区では, メキシコ マンネングサの葉の水ポテンシャルは低下が認められ, タイトゴ メも若干低下し，いずれの種類も水ストレスを受けていたと考え られる。しかし $3 \%$ 食塩水と $40 \%$ ポリエチレングリコール水溶 液とはほぼ同一の水ポテンシャルを示すにもかかわらず，夕イト ゴメの葉の水ポテンシャルは, 食塩水 $3 \%$ 区の方がより低い值を 示した。つまり水ストレスに加えて, 葉中に塩分が浸入したこと
による水ポテンシャルの低下であると言える。これらの結果は根 からの塩分の吸収による害であり, 本種においては根からの塩分 吸収を回避するような機能は働いていないと考えられる。しかし 茎葉に散布される場合には被害は少なく, タイトゴメの場合には 無施用区を上回る生育を示した。つまり自生地の海岸の岩場に生 育する夕イトゴメは，降雨時以外は常に乾燥条件下におかれてい るため, 根圈に塩分があったとしても吸収されることは少なく, また降雨時に吸水する時にはある程度希釈されていると考えられ る。しかし地上部への塩分の影響は極めて少なく，その耐塩性は 葉表皮の肥厚化やワックスの集積等の形態変化 ${ }^{1)}$ によるころが 大きいと考えられる。

\section{4. 結論}

セダム属数種の耐塩性について検討した結果, 海岸を自生地と する多汁なタイトゴメが最も耐性に優れ，多汁でない内陸性のッ ルマンネングサは最も耐性に劣った。いずれの種類も健全に生育 を営んでいる場合よりも水ストレス状態である方が而塩性が増大 することが明らかとなった。土壌中に食塩水が灌注されることに よる被害が大きく, 茥葉部に散布される場合には被害は認められ なかった。特にタイトゴメでは食塩水が散布されるとむしろ生育 が良好になったことから潮風にあ極めて耐性を示すあのと考えら れるが, 塩分の体内への浸入は影響が大きい。

よって臨海地等への導入にあたっては, 根圈からの塩分の吸収 をいかに回避するかが要点となる。

最後に本実験の実施にあたり, ご協力頂いた川口次代氏に深謝 致します。

\section{引用文献}

1) E.V.Maas \& R.H.Nieman (1978): 'Physi ology of plant tolerance to salinity', in "Crop Tolerance to Suboptimal Land Conditions", ASA Special Publication No.32

2) Ganzmann,R.J.,v. Willert,D.J. (1973) : N achweis eines diurnalen Säurerhythmus beim Halophyten Aster tripolium. Naturwissenschaften 59,422-423

3 ) Hanscom,Z,Ting,I.P. (1978): Responses of succulents to plant water stress. Plant Physiol.,61, 327-330

4 ) 飯島健太郎 (1995): 乾燥条件下におかれた 場合の Sedum 属の水ストレス反応について： ランドスケープ研究 58(5), 69-72

5 ) 飯島健太郎・近藤三雄（1996）：メキシコマ
ンネングサの光合成型ならびに生育に及ぼ す土培水分と気温の影響 : 東京農大農学集 報 41(3)，156-163

6 ）飯島健太郎・近藤三雄 (1998): 乾燥条件下 におけるメキシコマンネングサの光合成反 応と気温, 照度との関係 : 東京農大農学集 報 42(4), 274-286

7) Kluge, M. (1977): Is Sedum acre a CAM Plant?, Oecologia, 29, 77-83

8 ）間藤徹 (1997)：植物の耐塩性のメカニズム： 植物の化学調節 $32(2), 198-206$

9 ) 但野利秋 (1981)：作物の耐塩性とその機構 : 化学と生物 21(7), 439-445

10) Ting,I.P.,Hanscom,Z. (1977) : Induction of acid metabolism in Portulacaria afra. Plant Physiol.59, 511-514
11) Treichel,S. (1975): The effect of $\mathrm{NaCl}$ on the concentration of proline in different halophytes. Z.Pflanzenphysiol.76,56-68

12) Treichel,S.,Bauer,P. (1974): Unterschiedli che NaCl-Abhängigkeit des tagesperiodischen $\mathrm{CO}_{2}$ - Gaswechsels bei einigen halisch wachsenden Pflanzen. Oecologia 17, 87 $-95$

13) Winter, $\mathrm{K}$. (1973) : $\mathrm{CO}_{2}$ Fixierungsreaktionen bei der Salzpflanze Mesembryanthemum crystallinum under variierten Au $\beta$ enbedingungen. Planta 114, 74-85

14) Winter,K.,v.Willert,D.J. (1972) : NaCl-in duzierter Crassulaceensäurestoff wechsel bei Mesembryanthemum crystallinum. Z.Pflanzenphysiol.67, 166-170

Summary: The purpose of this study is to investigate the salt resistance of Sedum in order to determine if Sedum can be planted on seaside area.

(1) Salt tolerance was compared among 4 different Sedums (S. makinoi,S. mexicanum,S. oryzifolium and S. sarmentosum), that the shoot were soaked in seawater. In conclusion, S. sarmentosum, S. mexicanum and $S$. makinoi were sensitive to $\mathrm{NaCl}$, whereas $S$. oryzifolium was considered most tolerant. Injury symptoms appearing on shoot were severest as $\mathrm{Na}$ content in shoot increased. And the shoot of salt tolerance was considerable in the water stress as compared with watering.

(2) On the other hand, the growth response of Sedums (S. mexicanum, S. oryzifolium) under combination of $\mathrm{NaCl}$ concentration $(0,1.0,1.5,2.5$ and $3.0 \%)$ and treatment (watering and misting) was examined. The study evaluated the growth condition of the species using the fresh weight of the plant, number of shoot, and leaf water potentials. Injury symptoms appearing on shoot were watered with $2.5 \sim 3.0 \% \mathrm{NaCl}$ concentration were severest that $S$. mexicanum withered and growth of $S$. oryzifolium is less vigorous. These results way suggest that Sedum could not maintain a salt concentration at a lower level by a suppressive function to salt uptake through the root. However, the shoot of salt tolerance was considerable when it was misted with the nutrient solution of $\mathrm{NaCl}$. 